\title{
Margaret McCartney: Have we given guidelines too much power?
}

In this article (BMJ 2014;349:g6027, doi:10.1136/bmj.g6027) reference 4 listed an incorrect citation. The reference should be: Tomlinson LA, Abel GA, Chaudhry AN, Tomson CR,

Wilkinson IB, Roland MO, et al. (2013) ACE Inhibitor and Angiotensin Receptor-II Antagonist Prescribing and Hospital Admissions with Acute Kidney Injury: A Longitudinal
Ecological Study. PLoS ONE 8(11): e78465. http://journals. plos.org/plosone/article?id=10.1371/journal.pone.0078465

Cite this as: BMJ 2015;351:h5550

๑ BMJ Publishing Group Ltd 2015 